\title{
Cruces procesionales y cruces de término. Alcance teológico y social de sus particularidades iconográficas
}

\author{
María Elvira Mocholí Martínez \\ Universitat de València \\ m.elvira.mocholi@uv.es
}

RESUMEN: El reino de Valencia, como otros de la Corona de Aragón y del resto de la Península Ibérica, se mostró especialmente propicio al levantamiento de cruces de término; pero los pocos estudios académicos que les han prestado atención se han detenido en su aspecto estilístico, lo que ha llevado a no pocos investigadores a comparar estas cruces con las de orfebrería. Más allá de su decoración, sin embargo, sus respectivas tipologías iconográficas presentan sustanciales diferencias. La ubicación de las cruces de término, fuera del ámbito eclesiástico, su medio material y, sobre todo, su función, podrían haber determinado las diferencias iconográficas respecto a otras cruces y, por ende, las implicaciones teológicas de unas y otras. Aquellas formaban parte del ritual litúrgico de la Iglesia, mientras que estas formaban parte de la vida diaria de la comunidad y responden, por tanto, a la religiosidad popular más que a la religión oficial.

PALABRAS CLAVE: Cruz de término; Cruz procesional; Iconografía medieval; Ritos funerarios; Estudios visuales.

\section{Processional and Wayside Crosses. Theological and Social Significance of their Iconographic Particularities}

ABSTRACT: The kingdom of Valencia, other realms of the Crown of Aragon and the rest of the Iberian peninsula, proved to have a particular propensity for the erection of wayside crosses. The few academic studies that have paid attention to them have only taken into account their stylistic aspect, which has led a good few researchers to compare these works with goldsmiths' crosses. But beyond the decoration, their subjects differ substantially. The location of the wayside crosses, outside the ecclesiastic area, their medium and especially their utility might have determined the iconographic differences with regard to other crosses and hence the theological implications of the different types of crosses. The processional crosses were part of the liturgical ritual of the Church, whereas the wayside crosses were part of the daily life of the community and they answer, therefore, to popular religiousity rather than to the official religion.

KEYWORDS: Wayside Cross; Processional Cross; Medieval Iconography; Funeral Rites; Visual Studies.

Recibido: 28 de febrero de 2018 / Aceptado: 25 de abril de 2018.

Las cruces de piedra -también llamadas cruces de término o peirons- erigidas en el antiguo reino de Valencia presentan cierta homogeneidad tipológica que las distingue de otros conjuntos, lo que ha permitido extraer ciertas conclusiones sobre su función en la sociedad valenciana bajomedieval (Mocholí, 2017a, 2017b). En este trabajo, pretendemos relacionar las de término con otro conjunto de cruces también «consumido», en este caso, en territorio valenciano: las de orfebrería. Los estudios del arte valenciano afirman reiteradamente que las cruces de piedra «concebidas con carácter realmente monumental, son realizadas con una técnica depurada y minuciosa que parecen trasunto de las cruces de orfebrería realizadas en piedra", dado que «se rematan con elementos en forma de flor de lis en los extremos de los brazos, de manera muy parecida a los de las cruces procesionales» (Gracia, 1998: 153)'. Sin embargo, si observamos con más detenimiento, podemos comprobar que la correspondencia entre ambos tipos de obras es meramente formal². Por el contrario, la tipología iconográfica de cada uno de ellos presenta diferencias sustanciales, hasta el punto de poder individualizar tipos iconográficos que, si no les

Cómo citar este artículo: MOCHOLÍ MARTíNEZ, María Elvira, "Cruces procesionales y cruces de término. Alcance teológico y social de sus particularidades iconográficas", Boletín de Arte-UMA, n. ${ }^{\circ}$ 39, Departamento de Historia del Arte, Universidad de Málaga, 2018, pp. 183-194, ISSN: 0211-8483, DOI: http://dx.doi.org/10.24310/BoLArte.2018. v0i39.4246 
son exclusivos, sí son predominantes. Bien es cierto que hay excepciones, pero no son suficientes para considerar que las cruces de piedra son un «trasunto» de las procesionales.

Más allá de su afiliación estilística y sus delicados ornamentos o de los remates «en forma de flor de lis» que comparten unas y otras, es evidente que al tratarse de crucifijos en ambos casos, se han visto como imágenes equivalentes y, por tanto, se ha concluido sin más que unas copian a las otras, las de piedra a las de metal. La diferencia en el material, impuesto por la ubicación y el uso de cada tipo de cruz, se ha visto como algo anecdótico. Sin embargo, ni uno ni otro, ni el material -o el medio como diría Belting (2007)³-, ni mucho menos el uso, o la función, son tan intrascendentes como se ha pretendido, pues sin lugar a dudas han determinado el programa iconográfico de las cruces procesionales, por un lado, y de las de término, por otro. Sin ir más lejos, la posibilidad de insertar esmaltes en las primeras amplía el espacio susceptible de recibir decoración figurativa, lo que aumentaría la complejidad de su programa iconográfico. En cualquier caso, según Cots Morató (2012: 48), la iconografía de las cruces procesionales valencianas «sigue las directrices del arte europeo de cada época» y, hasta donde hemos podido constatar, así es, al menos a grandes rasgos ${ }^{4}$, a diferencia de las de término, que presentan una singularidad tipológica con respecto al mismo tipo de cruces del resto de Europa.

\section{Un tipo iconográfico diferenciador: el Tetramorfos}

Pese a lo dicho anteriormente, datada en la segunda mitad del siglo XIV, una de las primeras cruces de término de las que tenemos noticia y además se ha conservado en perfecto estado, supone una de las pocas excepciones a las que nos hemos referido. Se trata de la cruz procedente del antiguo camino real de Valencia en Xàtiva [1]. Ni que decir tiene que el anverso de las cruces de término está invariablemente ocupado por el Crucificado, acompañado o no por las figuras de María y san Juan Evangelista, como en la mayoría de las procesionales. También en la cruz de Xàtiva, la presencia de estas figuras, con gestos evidentes de dolor, completa la escena del Calvario. Hasta aquí, la tipología iconográfica de la obra setabense es representativa de la del resto de cruces, tanto las de piedra como las de metal, y tanto las va- lencianas como las del resto de Europa. Llama la atención, sin embargo, que en los extremos de los travesaños de la cruz se encuentren los símbolos de los cuatro evangelistas.

El Tetramorfos, determinado aquí por filacterias, en las que en su día pudo haber un texto identificativo ${ }^{5}$, ya que todas las cruces estaban pintadas, supone una rareza iconográfica en una cruz tan temprana. Son muy pocas, de hecho, las cruces de término medievales que lo incluyen. Una de ellas es la creu dels Avinyó o del Fossar en Catí, una obra igualmente temprana, de 1374, cuyo Tetramorfos aparece en el capitel, junto a la inscripción que la data y la identifica con la cruz cementerial de los Avinyó. La obra, por tanto, se encontraba en el camposanto de Catí, a diferencia de la mayoría de cruces de piedra, que solían flanquear los caminos.

De principios del siglo XV, es la cruz del camino de Orihuela en Elche que presenta una doble particularidad respecto a las anteriores. Por un lado, los evangelistas, también en los extremos de los travesaños, se presentan en forma humana y además flanquean a la omnipresente figura de la Virgen con el Niño, que prácticamente siempre señorea el reverso de las cruces de término. Por último, ya de finales de esta misma centuria, es la creu de l'Assagador en Peñíscola. Aunque totalmente reconstruida, se han conservado restos e imágenes fotográficas de símbolos de evangelistas en los extremos de la cruz.

Así pues, aunque puedan parecer muchas, la presencia del Tetramorfos en sólo cuatro de las decenas de cruces de término que hemos tenido ocasión de estudiar, unas 197, indica que no era una tipología abundante. Si bien es cierto que, debido a la desaparición de la mayoría de ellas, no tenemos información de la tipología iconográfica de gran parte de las mismas. Por el contrario, en las cruces de orfebrería es frecuente la presencia del Tetramorfos, bien en los extremos de los travesaños o junto a estos, si aquellos están ocupados, pues el medio metálico se presta a una mayor profusión icónica.

A finales de la Edad Media, hacía ya mucho tiempo que los cuatro seres de las visiones de Ezequiel $(1,4-5 ; 1,10)$ y del Apocalipsis (4,6-7) habían sido interpretados como símbolos de los evangelistas ${ }^{6}$ y en referencia al Evangelio es como hay que interpretarlos también en las cruces procesionales. Estas obras deberían mantener la distribución jerárquica habitual de los cuatro vivientes que, en otro tipo de imágenes, se disponen en cuatro esquinas alrededor de la 
figura Cristo, siendo habitual que san Mateo y san Juan ocupen el nivel superior. Sin embargo, debido a la disposición romboidal de los extremos de las cruces, es san Juan el que predomina sobre todos los demás. No obstante, las metálicas no permiten extraer conclusiones definitivas, pues no se puede garantizar la disposición del Tetramorfos cuando se sitúa en placas fácilmente removibles e intercambiables, aunque Cots Morató (2012: 54) localiza abajo a san Mateo, san Lucas a la derecha y san Marcos a la izquierda. Sin embargo, en la cruz del camino de Valencia en Xàtiva [1], es san Marcos quien se encuentra a los pies de Cristo, mientras que san Mateo está a su derecha y san Lucas a su izquierda.

Conviene hacer notar que el Tetramorfos, pese a tratarse de cruces tan tempranas como ésta, es una tipología arcaica a finales de la Edad Media, pues a partir del siglo XIII, en otros contextos, como el del Juicio Final, Cristo en majestad rodeado de los símbolos del Tetramorfos es sustituido por Cristo Varón de Dolores -con las palmas agujereadas y la llaga del costado-, flanqueado por ángeles que sostienen instrumentos de la Pasión o rodeado de la Virgen y el apóstol Juan (González, 2011: 65; Réau, 2006: 50), como al pie de la cruz. Las cruces procesionales y algunas de piedra -las modernas como luego veremos- incorporan los símbolos de los evangelistas, aún cuando flanquean imágenes del Calvario, con los personajes sagrados que les han sustituido. Así pues, la humanización de Cristo que, según Réau, resultaba más elocuente para el corazón de los fieles, no hizo desaparecer de las cruces procesionales a los anteriores compañeros de la Maiestas Domini, tipo iconográfico que siguió estando presente en el reverso de algunas de ellas y cuya majestad enfatizaba el Tetramorfos, aún cuando no compartieran espacio.

Entre otros medios, el Tetramorfos sobrevivió en las cruces de orfebrería y en las de piedra en época moderna, pese a notables y esporádicos ejemplos medievales como los expuestos anteriormente. Entre ellos, resulta especialmente curioso el caso de la cruz ilicitana, en la que se han representado los evangelistas en lugar de sus símbolos, como será habitual en las piezas metálicas a partir del siglo XVI, según ha constatado Cots Morató (2012: 55). Al rodear la imagen de Cristo o de la Virgen, los cuatro evangelistas se asimilan a puntales ${ }^{7}$ de la fe cristiana, pues su obra contiene toda la doctrina evangélica, que se compendia en el misterio de la cruz (De Carlos, 2001). En las procesionales, además,

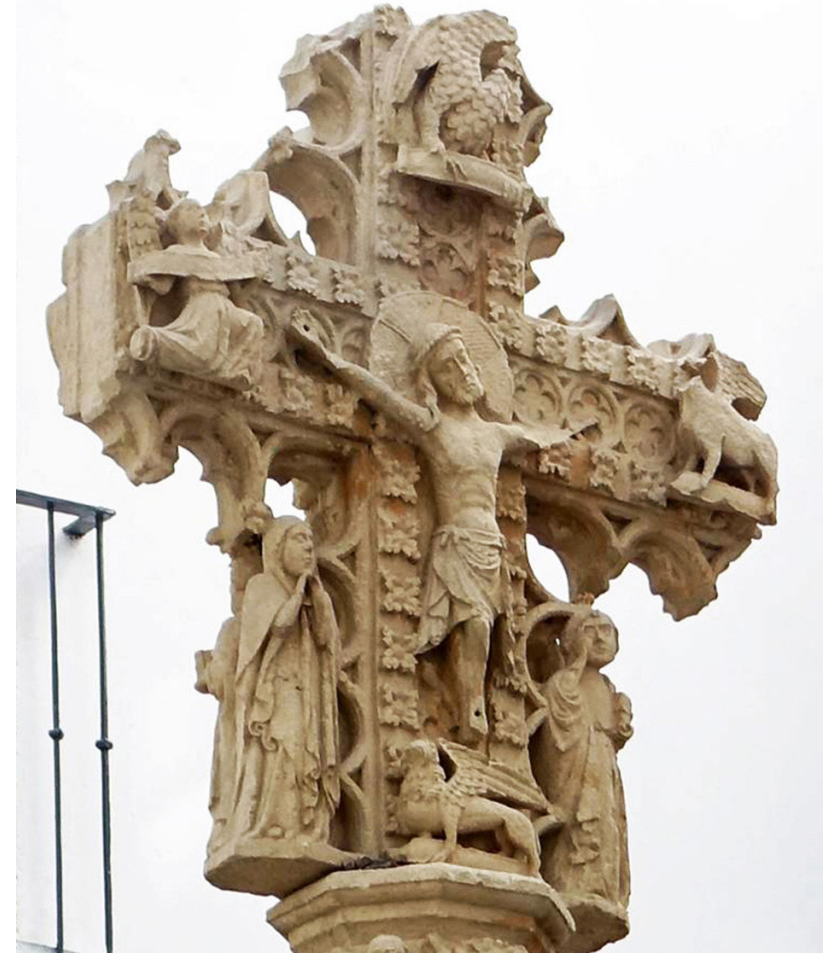

1. Cruz del camino de Valencia, segunda mitad del siglo XIV. Museo de Bellas Artes de Xàtiva (Valencia)

el Tetramorfos representa la difusión de la palabra y, en este sentido, su presencia es totalmente pertinente en estas cruces, puesto que, cuando no se utilizaban, se colocaban en el altar, en el lado del Evangelio (Hourihane, 2005, 51 y 61). Así pues, las cruces de orfebrería soportan una carga teológica mayor, debido a su ubicación y función litúrgica, que las cruces de término.

Por otro lado, aunque no siempre, el Tetramorfos aparece con frecuencia en el reverso, cuyo centro puede estar ocupado por la imagen de la Virgen con el Niño, como ya hemos mencionado. La coincidencia de ambos en el mismo lado de la cruz, que se mantiene durante toda la Edad Media, puede responder a la relación de los evangelistas con la Encarnación de Cristo, en tanto que testigos de la maternidad divina de María (Bango, 1984: 8). Así ocurre, por ejemplo, en la creu grossa de la iglesia arciprestal de Sant Mateu, datada en 1397. La correspondencia entre la divina Encarnación de Cristo y la Eucaristía, o más concretamente la transubstanciación, ya fue puesta en evidencia en las 


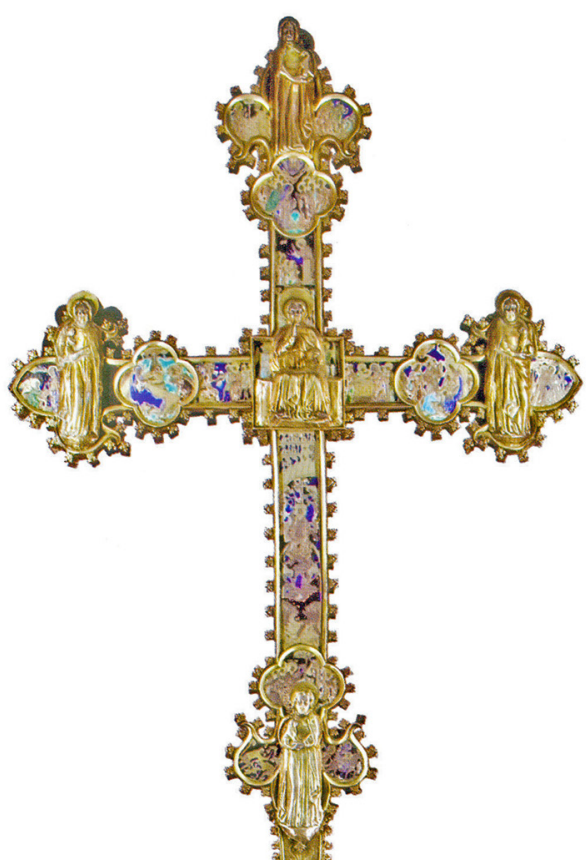

2. Cruz mayor de Xàtiva, ca. 1400. Colegiata de Xàtiva (Valencia)

cruces de término (Mocholí, 2017b), donde la presencia mariana es aún más abundante que en las procesionales. Pero también resulta evidente en otro tipo de obras, como en el retablo eucarístico de Villahermosa del Río, donde un recipiente parecido a una píxide se aprecia en la imagen de la Anunciación y, en la Natividad, un fardo con una bota de vino remite a las especies eucarísticas y el pesebre con el Niño al altar (Favà, 2005-2006: 114-116).

La cruz como epítome de la Redención e imagen del sacrificio eucarístico

La cruz, en todo caso, manifiesta el misterio de la Redención: la Pasión y Victoria de Cristo sobre el mal. Y, destinadas a reforzar el mensaje redentor, las cruces de orfebrería combinan imágenes narrativas y conceptuales. Entre las segundas, todas ellas relacionadas con el sacrificio cristológico, predomina el pelícano ofreciendo su sangre a sus crías, en el travesaño superior del anverso (cruz de Sant Mateu, siglo XIV [3]). Esta imagen se encuentra casi totalmente ausente de las cruces pétreas, con la única salvedad de la cruz de Cullera, del siglo XV. Menos frecuente en las cruces procesionales es el Agnus Dei y los ángeles con instrumentos de la Pasión que, a diferencia del cordero, aparecen esporádicamente en el capitel de alguna cruz de término (cruz del camino de Alicante en Elche, ca. 1400). En lugar del pelícano, sobre el Crucificado, puede aparecer Dios Padre (cruz mayor de Xàtiva, ca. 1400 [2]) o el Espíritu Santo, mientras que en el reverso, son habituales las imágenes de Cristo en Majestad o Cristo juez (cruz mayor de Xàtiva [2]), pero también de María, generalmente acompañada del Niño.

Entre las imágenes narrativas, naturalmente destacan las escenas de la Pasión (cruz de Sant Mateu [3], cruz mayor de Xàtiva [2]), a diferencia de las cruces de término, en las que no se prodigan. Sí lo hacen, en cambio, otros tipos iconográficos presentes en las cruces metálicas, como la Natividad u otros episodios de la vida de la Virgen y de la infancia de Cristo. En los capiteles de la cruz del camino de La Jana en Traiguera y de la creu dels Brusca o d'en Moragues en Catí, por ejemplo, coincide aquel con la Adoración de los Magos; y en el de la creu de Cap de Vila o de la Plaça Nova en Cinctorres, del siglo XV [4], este último tipo iconográfico se combina con la Coronación de la Virgen.

Aunque en menor medida que en las de metal, la imagen de Adán saliendo de su tumba aparece en algunas cruces de término medievales a los pies del Crucificado (creu dels Brusca o d'en Moragues en Catí, creu de Cap de Vila o de la Plaça Nova en Cinctorres [4], creu de l'Assagador en Peñíscola, cruz de Aliaga en Vila-real). Según la tradición, el Gólgota acogía el cráneo de Adán, por lo que se había convertido en un lugar de muerte y pecado. La santificación del monte Calvario se produjo tras la crucifixión del segundo Adán, cuya sangre limpió los pecados del primero. Así pues, a semejanza de la cruz de Cristo, con la que el Mesías venció al demonio en el Gólgota, se levantaban cruces en la cima de las montañas, uno de los lugares considerados malditos (Martin y Martin, 1977: 35) y en los que la erección de santuarios y cruces tenía como propósito vencer el mal que residía en ellos. La duda planteada por Duran-Porta es si efectivamente el personaje que resucita a los pies de Cristo es Adán y no Lázaro, pues desde en el siglo XI, si no antes, se había representado al segundo saliendo de un sepulcro horizontal. No hay duda sobre la identidad de Adán cuando se representa una calavera a los pies de la cruz, pero no está 


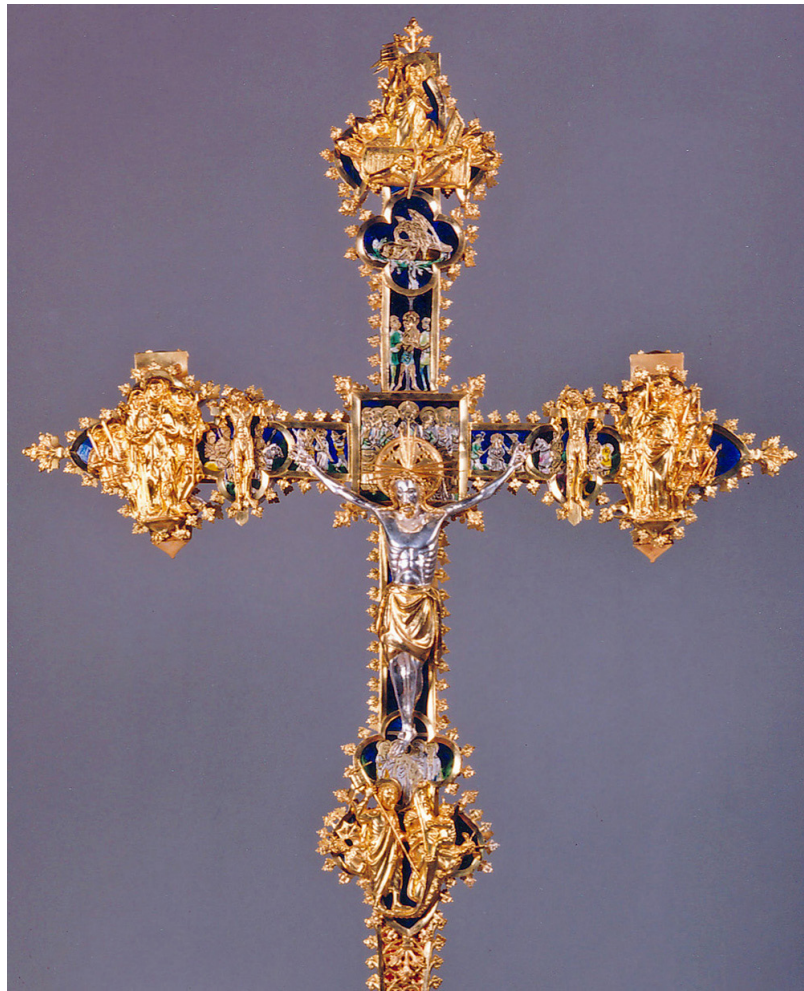

3. Cruz procesional de los Comí, s. XIV. Iglesia arciprestal de Sant Mateu (Castellón)

tan claro cuando se trata de su resurrección, pues se puede confundir con la de Lázaro. No obstante, en la creu de Cap de Vila o de la Plaça Nova de Cinctorres [4], podemos identificar a Adán sin lugar a dudas, pues se dirige en oración a la imagen del Varón de Dolores.

El autor considera que «la narració del miracle evangèlic havia de tenir una repercussió més ampla i era més pròxim al sentit humanitzat i expressiu de la devoció popular de l'època que no pas la més intellectualitzada resurrecció de l'Adam» (Duran-Porta, 2009: 52-53). A juzgar por su escasa presencia en las cruces de término, la imagen en cuestión podría tratarse del primer hombre, pues dado su carácter popular, cabría esperar una mayor generalización de la supuesta imagen de Lázaro, atendiendo a la carga piadosa y caritativa del tipo iconográfico, la que también parecen responder las cruces procesionales (Duran-Porta, 2009: 56). Efectivamente, la cruz procesional estaba presente en la procesión del viático, en la administración del último sacramento y, en general, en la liturgia funeraria, como luego

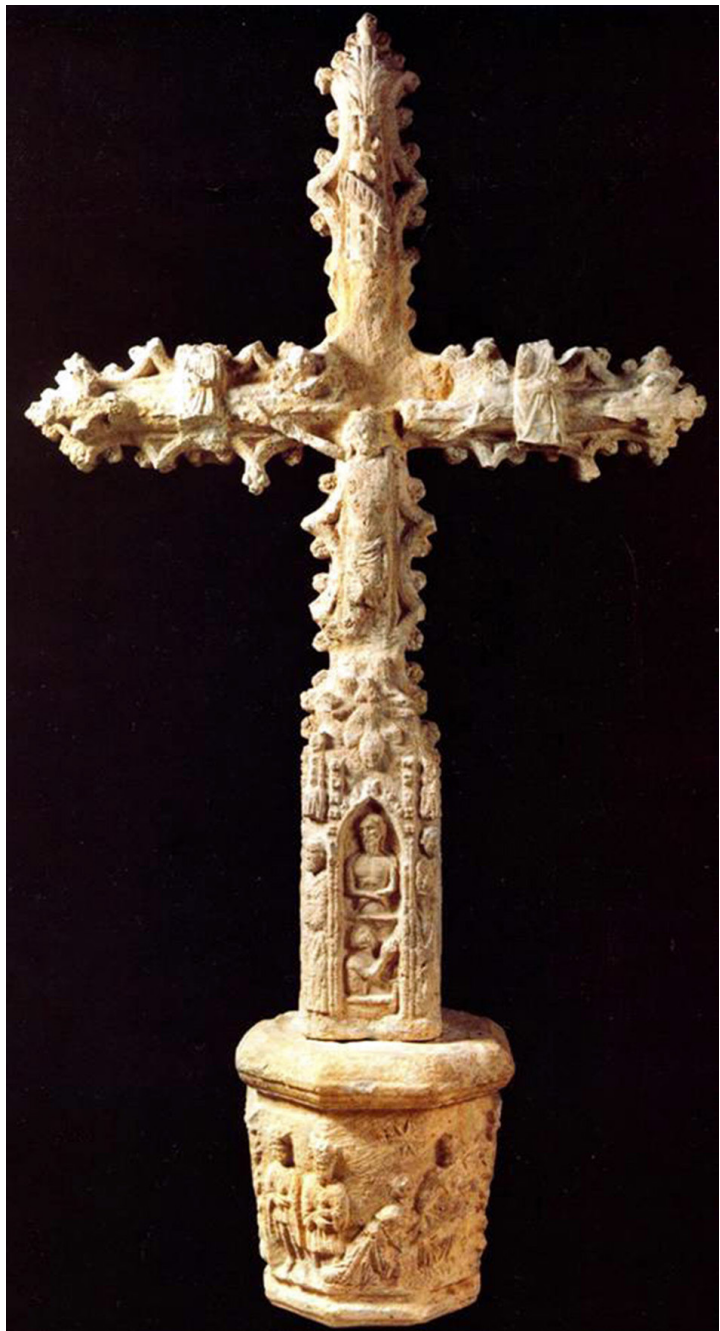

4. Creu de Cap de Vila o de la Plaça Nova, s. XV. Iglesia parroquial de Cinctorres (Castellón)

veremos. Aunque, como también tendremos ocasión de comprobar, la tipología iconográfica de este tipo de obras no respondía necesariamente a su uso fuera del espacio eclesiástico.

Por otro lado, en los siglos XIV y XV, el tipo de la bajada a los infiernos (cruz de Sant Mateu [3], o cruz mayor de Traiguera, de 1415-1419) sustituye en numerosas cruces procesionales a la resurrección de Adán, más propia del siglo XIII (Llompart, 1974: 93). Ambos tipos

[...] poden interpretar-se, doncs, com a efectes de la reconciliació entre Déu i la humanitat de resultes del Sacrifici de Crist. 


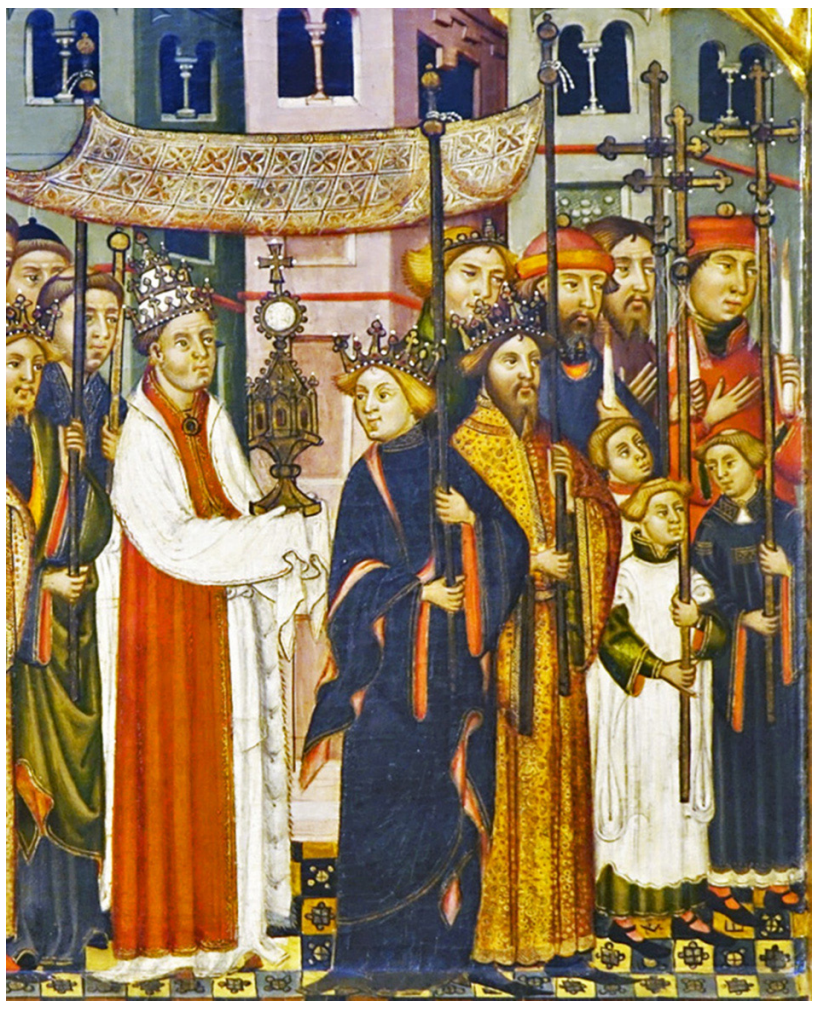

5. Llorenç Saragossà (atribuido), Retablo de la Eucaristía (detalle), 13851390. Iglesia parroquial de Villahermosa del Río (Castellón)

En aquest sentit, totes dues imatges reforcen i potencien el contingut eucarístic de les creus processionals, i complementen el sentit passional i salvific amb què tradicionalment s'han vist associades. Tot apunta, doncs, que cal considerar fonamental la festivitat del Corpus Christi en el desenvolupament d'aquest tipus d'objectes a la baixa edat mitjana, tant des del punt de vista purament material com, singularment, pel que fa a la rica iconografia que s'hi desplega (Duran-Porta, 2009: 58).

Y, si la imagen de Adán (o Lázaro) es escasa en las cruces de término, la bajada a los infiernos se encuentra totalmente ausente, hasta donde hemos podido comprobar. Quizás, siguiendo la teoría de Duran-Portan, el también «intelectualizado" tipo iconográfico de la Anástasis, Cristo descendiendo al limbo de los patriarcas, no tenía cabida en una serie de obras de consumo eminentemente popular, pese a coincidir en su carácter eucarístico (Mocholí, 2017b) con las cruces procesionales.
Este carácter eucarístico de las cruces de piedra no requería, sin embargo, de una imagen manifiesta de la institución sacramental, pues tampoco hemos registrado en éstas ninguna representación de la Última Cena, que sí centra, por el contrario, el reverso de algunas cruces metálicas (y a veces el anverso, como en la cruz de Sant Mateu [3]). Este episodio remite a la Eucaristía y por extensión a la Crucifixión de Cristo, el auténtico sacrificio rememorado todos los días en el altar. Pero más allá de la actualización del mismo, con la consiguiente elevación y contemplación de la hostia, a la que se atribuían propiedades apotropaicas (Rubin, 1992: 50), la devoción hacia la humanidad de Cristo que se da a partir del siglo XII, da vida a nuevas formas rituales como la devoción extra missam, la exposición del Santísimo Sacramento o las procesiones eucarísticas (Herráez, 1994: 784). Especialmente estas últimas ofrecen al fiel la posibilidad de una mayor cercanía al misterio sacrificial; cercanía a la que contribuirán las cruces, no sólo las procesionales sino también las de término, relacionadas igualmente con manifestaciones del culto al Corpus Christi, en tanto que imágenes del sacrificio originario de Cristo en la cruz.

El fervor por la elevación y contemplación de la hostia, cuyo apogeo tuvo lugar en el siglo XIV, coincide con la creación del ostensorio o custodia, que permite la visibilidad del cuerpo de Cristo en exposiciones eucarísticas y en procesiones públicas, preponderantes en la vida religiosa bajomedieval, como la de Corpus Christi. Acompañando a la custodia, salían imágenes, reliquias y cruces de orfebrería [5]. Estas últimas recreaban, en las procesiones, la de Cristo camino del Calvario y en las cruces que, por ejemplo, marcaban los límites de la parroquia o cuando eran llevadas desde el altar al espacio del devoto en el interior de la iglesia, evocaban el sacramento de la Eucaristía al presentarse entre dos velas y junto al sacerdote, como cuando éste alzaba la hostia (Hourihane, 2005: 9, 51 y 62). También las cruces de término eran representaciones de la Eucaristía por lo que permitían disfrutar de un trasunto de la muy extendida comunión visual.

Por ello, la obsesión por la ostentatio eucharistiae también coincide cronológicamente con la erección masiva de cruces en los caminos de salida de las poblaciones -mientras que, como luego veremos, en época moderna su emplazamiento se diversifica- $y$, en menor medida, en el acceso a santuarios, como el de San Pedro de Albocàsser o los 
de Santa Lucía y Vallivana de Morella. La ubicación de la mayoría de las cruces de término no sólo permitía al devoto obtener una última visión del sacrificio de Cristo antes de enfrentarse a los peligros de lo inhóspito, sino que el programa iconográfico de las mismas completaba su condición salvífica. Entre las imágenes que contribuyen a este fin se encuentran la de determinados santos.

\section{Las cruces procesionales en el ámbito funerario}

En las cruces de orfebrería, desde el siglo XIV, se introducen santos de devociones populares. En este aspecto, la tipología iconográfica de ambos tipos de cruces tiene puntos en común, pero en las de piedra los santos se ubican en los travesaños, mientras que en las de metal, aunque sólo a partir del siglo $\mathrm{XV}$, centran el reverso cuando son titulares de la iglesia o santos locales. La Virgen con el Niño señorea invariablemente el reverso de las cruces de término, pero varía la pareja de santos que acompaña a María. Los más habituales son Pedro y Pablo, en representación del colegio apostólico o como intercesores a la hora de la muerte, o dos santas, entre las que predominan Lucía, Catalina o Bárbara (creu de les Canals en La Mata, ca. 1440 [5]), esta última una de las santas eucarísticas y protectora contra la muerte súbita, junto con santa Catalina. De este modo, los principales tipos iconográficos de las cruces de piedra, interpretados según su localización y su relación con antiguas creencias asociadas al más allá (Mocholí, 2008), podían explicarse en relación con la muerte, sobre todo con la buena muerte y la esperanza de soslayar los peligros que podría acarrear una defunción súbita y repentina, que privara al fiel de cualquier posibilidad de salvación para su alma.

Así pues, con las excepciones anteriormente expuestas y más allá de la imagen del Calvario, las cruces de término difieren iconográficamente de las procesionales. Esta diferencia no depende únicamente de la menor cercanía al pueblo de estas últimas, pues no son inaccesibles. Como ya hemos avanzado, la cruz de orfebrería salía con frecuencia al encuentro del devoto y no sólo podía ser contemplada durante la liturgia religiosa, sino también en la calle y en fiestas públicas o privadas (Herráez, 1994: 83). Sin embargo, aceptado como está que las imágenes no son únicamente la Biblia del pueblo, la tipología iconográfica de estas cruces

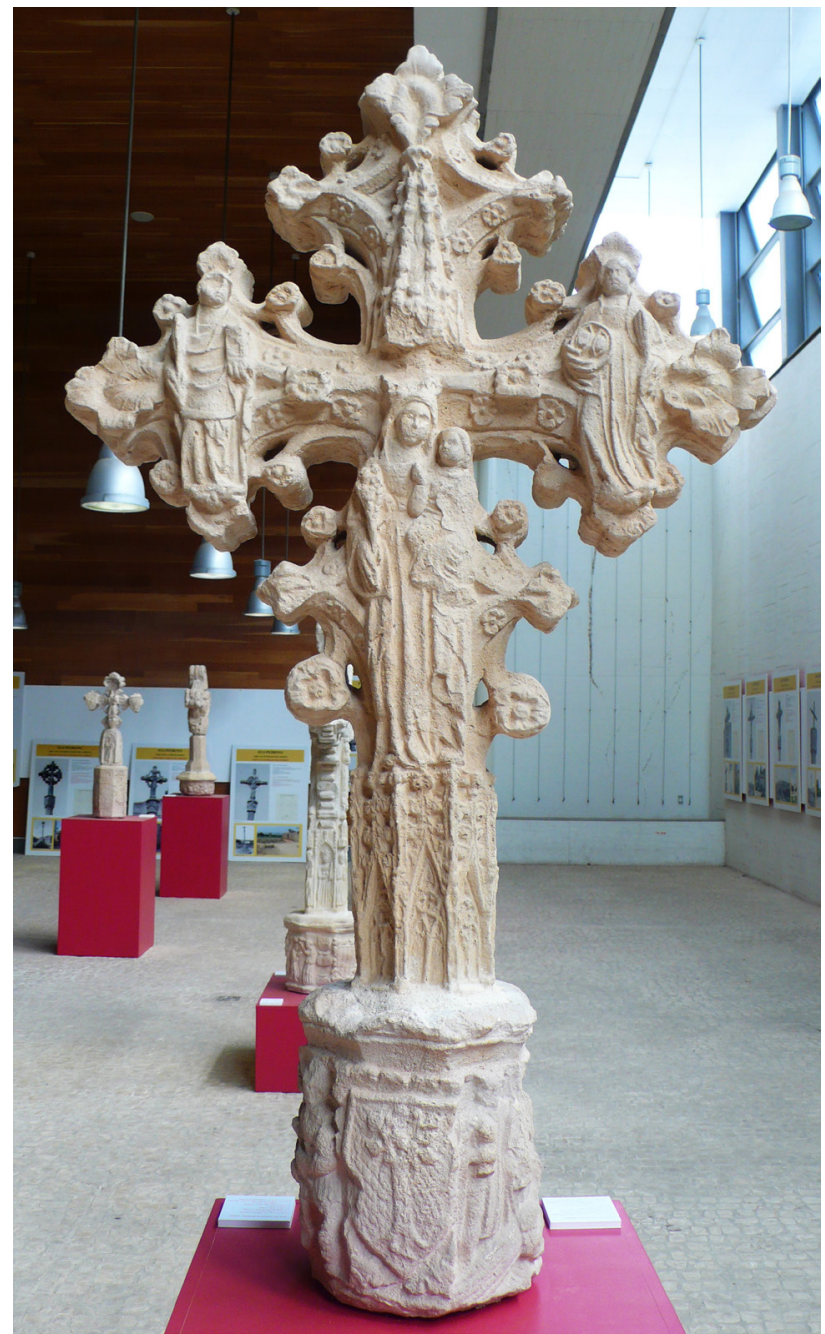

6. Creu de les Canals, ca. 1440. Ayuntamiento de La Mata

no se explica en virtud de un público potencial debido a su uso fuera del altar, pues no fueron exclusivamente realizadas para un espacio laico y en continuo contacto con la población, como las de término. Si bien, más allá del cumplimiento de sus funciones litúrgicas y procesionales, la constante inmersión de cruces de orfebrería en la vida diaria de la población, por ejemplo en las batallas ${ }^{8}$ y como protectoras contra el mal, acortaría la distancia funcional entre ambos tipos de cruces.

Por otro lado, las cruces procesionales estaban presentes en la administración de los últimos ritos y en el encabezamiento de procesiones funerarias. El Ordo Visitandi 


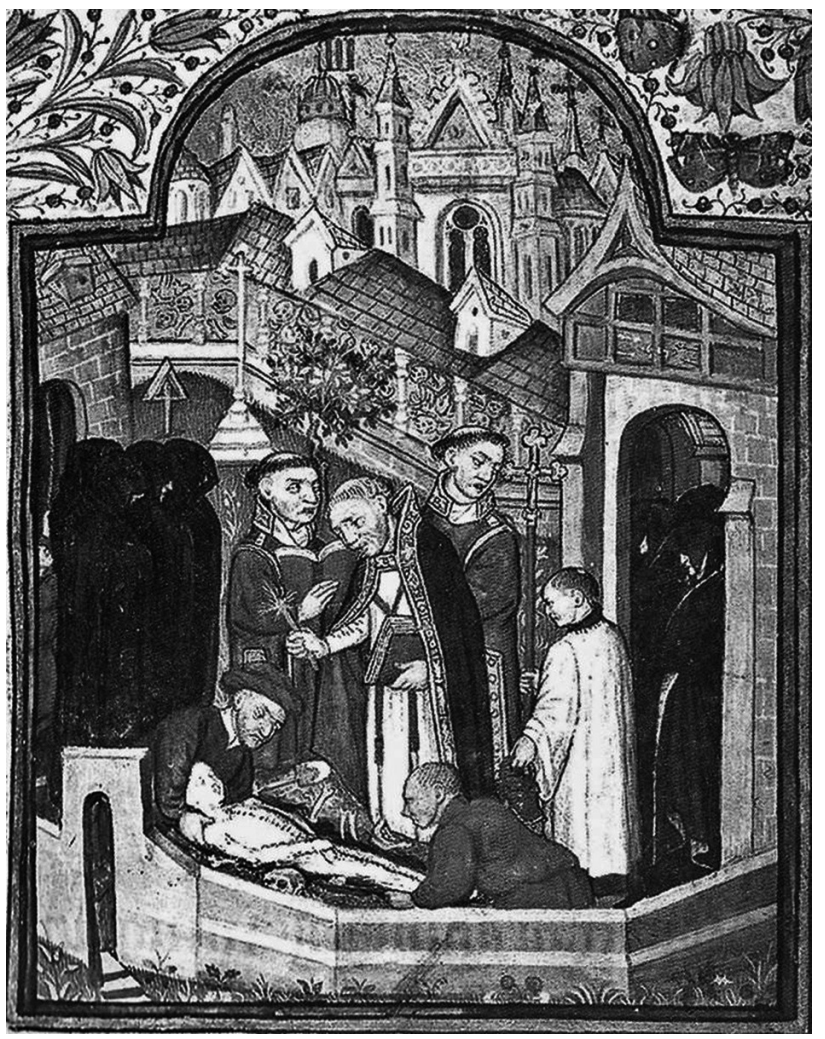

7. Libro de Horas de Marie de Rieux, 1440-1450. Nueva York, Morgan Library, M. 190, fol. $1 r$.

estipulaba que el sacerdote debía sujetar un crucifijo frente al moribundo en todo momento, para protegerlo contra el demonio, permitirle adorar al redentor y recordar la pasión que padeció por sus pecados, así como la resurrección y salvación futuras. Así, unidas muerte y resurrección, la cruz dejaba de ser un recuerdo pasivo para renovar su poder como símbolo con el que guiar al difunto al más allá, convirtiéndose en una parte integral del arte de buen morir, que incluía confesión, comunión y unción. Su activa funcionalidad en el ámbito funerario se corresponde con el arraigo popular que adquirió la cruz en el siglo XV, como se desprende de su uso en el entierro de laicos (Hourihane 2005: 30-39, 50), según se puede constatar en la miniatura de la época [7].

También las cruces de piedra, al menos en otros países, tenían una notable presencia en el ámbito funerario [7]. En Inglaterra, por ejemplo, los primeros misioneros erigieron grandes cruces en medio de los cementerios, pues las tumbas no empezaron a señalarse con cruces hasta algunos siglos después. Durante la baja Edad Media, la cruz cementerial formó parte del ceremonial de la iglesia, presidía a los que se enterraban a su sombra y recordaba la resurrección a los que la contemplaban. Algunas disponían de un nicho, que podría albergar las luces para los muertos o servir de lugar de reposo para la hostia (Benson, 1982: 87; Nelson, 1952: 75). $Y$ en territorio valenciano, donde se tiene pocas noticias de este tipo de cruces y se han conservado menos todavía (creu dels Avinyó o del Fossar en Catí, cruz de Santa Bárbara o del Fossar en Sant Mateu y creu del Fossar en Vila-real, ambas del siglo XV), también era el lugar donde se «cantava la darrera absolta del ritual funerari abans de la inhumació del cadàver» (Pitarch, 2005: 103) .

En las pocas imágenes que trasladan icónicamente este ritual, aparece siempre una cruz procesional en mano del sacerdote, no un crucifijo. Lo que llama la atención, no obstante, es que la mayoría de ellas han sido representadas con absoluta sencillez. Pese a tratarse inequívocamente de cruces procesionales, en el mejor de los casos sólo aparece el Crucificado, mientras que el resto no presenta ningún tipo de figuración [7]. Naturalmente, el medio empleado en su representación no favorece la descripción detallada de las cruces, sin embargo, cabe la posibilidad de que su sencillez responda a las necesidades del devoto en su simple y directa aproximación a la imagen del Redentor durante su último trance. De hecho, Hourihane plantea que existían dos tipos de cruces procesionales: unas más valiosas para los acontecimientos importantes y otras menos decoradas para su uso diario (2005: 14), que incluiría los ritos funerarios. De ser así, estas imágenes ratificarían la anterior afirmación sobre la disociación entre la tipología iconográfica de las cruces procesionales y su cercanía a la población, así como el carácter más popular de la de las cruces de término.

\section{Correspondencia iconográfica de las cruces modernas}

Respecto a su tipología iconográfica, mientras que las cruces de orfebrería renacentistas mantienen la medieval (Cots, 2012: 63), las de piedra, ahora sí, toman como prototipo la de aquellas sin una finalidad concreta. Un magnífico ejemplo es la renacentista cruz de la ermita de San José y Santa Bárbara de Xàtiva, cuya iconografía es la característica del siglo 
XVI. En el anverso, el Tetramorfos rodea a Cristo crucificado en los extremos de los travesaños, mientras que la Virgen con el Niño sigue presidiendo el reverso, pero ahora lo hace apoyada en una media luna. Sobre su cabeza, un busto de Dios Padre sostiene un orbe rematado por una cruz, mientras que con la otra mano señala a María, instrumento de la encarnación de su Hijo, que sostiene en sus brazos. A ambos lados, asoman los dos titulares del santuario, si bien sólo santa Bárbara es inequívocamente reconocible por la torre con tres ventanas -en alusión a la Trinidad-.

También apea sobre una luna la imagen de la Virgen con el Niño que centra el anverso de la cruz de Meliana en Foios, de 1536 [8]. Sobre María aparece un sol y a sus pies la imagen de san Bernardo, y a ambos lados las figuras de san Vicente Mártir y san Vicente Ferrer. Ninguno de los tres forma parte de la tradición iconográfica de las cruces de término, a excepción del segundo que podría aparecer en las medievales cruces de Santa Lucía en Morella o del Pla de la Font en Xert. En el anverso, los símbolos de los evangelistas, cada uno sobre una filacteria, rodean al Crucificado. En la creu de les Eres de Albaida, ya de principios del siglo XVII, el Tetramorfos rodea a María, sin el Niño, en el reverso de la cruz. El crucificado, por el contrario, se encuentra acompañado de san Vicente Ferrer y santo Domingo, mientras que arriba asoma el busto de Dios Padre y a los pies del Hijo la paloma del Espíritu Santo completa la Trinidad.

El acceso a algunos templos seguía señalándose en el siglo XVI, como en el santuario de Sant Pau de Albocàsser, pero también frente a la iglesia arciprestal de Santa María de Morella, en el centro de la población. En Traiguera, por el contrario, no sólo se instala una cruz cubierta de carácter tardorenacentista en la explanada del santuario de la Virgen de la Fuente de la Salud, en cuyo anverso Dios Padre sostiene la cruz de Cristo, sino que en el siglo XVI se distribuyen siete cruces más a lo largo de todo el camino de acceso desde la población. Aunque su iconografía no está clara, debido a su destrucción y a que los documentos gráficos y literarios que se conservan son contradictorios, las fotografías parecen indicar que las imágenes de los evangelistas, con sus símbolos, ocupaban algún capitel, como en la cruz de la arciprestal morellana.

Sin embargo, las cruces modernas no necesariamente se alzaron en lugares carentes de ellas, ya que es difícil saber si una cruz ha sustituido a otra allí donde no hay

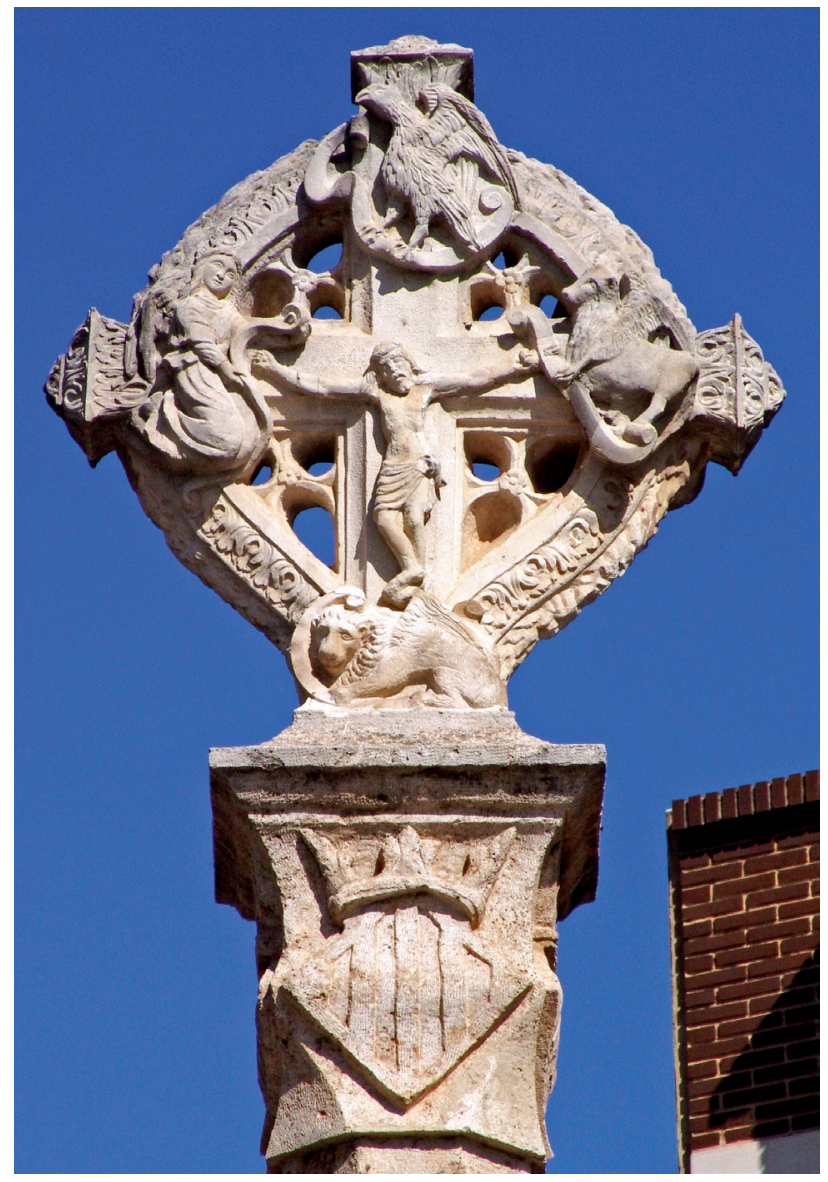

8. Cruz del camino de Meliana, 1536. Plaça de la Creu de Foios

documentación que lo confirme. No obstante, el predominio de restos medievales alrededor de los caseríos y el de cruces modernas en otros enclaves, como plazas, parece responder a un cambio, o más bien a una diversificación, en la distribución de estas obras a partir del siglo XVI. La restringida localización de las cruces más antiguas que se conservan en Valencia, de los siglos XIV y XV, responde a las implicaciones funcionales que ya hemos comentado; mientras que la expansión de cruces pétreas de época moderna hacia lugares donde no era habitual encontrarlas, comporta la pérdida de su función en las salidas de las poblaciones por su desplazamiento hacia el interior. Así pues, la ubicación de estas cruces, paralela al incremento de su trasfondo teológico, con la introducción de una mayor complejidad en el programa iconográfico, que se asemeja al de las cruces procesionales, comporta una banalización de estas obras ${ }^{10}$, 
sin que se lleguen a abandonar sus funciones originarias o su significación religiosa disminuya o desaparezca.

En conclusión, en época medieval, las cruces procesionales se cargan de una significación teológica que responde a un uso litúrgico, mientras que las de término están más sujetas a la devoción popular, pese a concesiones como la incorporación de los apóstoles Pedro y Pablo. Sin embargo, al margen de la liturgia en el interior del templo, las cruces de orfebrería cumplen una función similar a aquellas o al menos asociada con las mismas preocupaciones que habrían propiciado la erección de cruces de piedra en los caminos de salida de las poblaciones, pues las procesionales están presentes en el momento de la (buena) muerte y las de término pretenden alcanzarla.

Pero la modernidad banalizará el uso de estas obras que, como hemos visto, se elevarán en mayor número de espacios y perderán su carácter protector contra la muerte repentina pasando a convertirse en un sencillo exponente de la piedad cristiana, al mismo tiempo que produce una relativa uniformización iconográfica con las cruces procesionales.

\section{Notas}

1 Simó llega a decir incluso que las cruces de piedra del Maestrazgo, en Castellón, con sus pulcros y afiligranados trabajos en piedra tallada, eran «imitadoras [...] de las cruces de orfebrería de los talleres de San Mateo y de Morella» (Simó Castillo, 1986: 199).

2 El ejemplo más evidente de la relación entre ambos tipos de cruces es el capitel o macolla de la cruz de término de Portell de Morella, labrada a modo de nudo con cabujones en losanje, como en el cáliz de la parroquia o en la cruz procesional de Cinctorres (Zaragozá Catalán, 1999: 11-12).

3 Respecto al material, aunque a la hora de definir las cruces de término o peirons, no haríamos distinción entre las de piedra y las de madera o metal, en esta ocasión nos centraremos únicamente en las primeras.

4 Si bien había cruces procesionales en toda Europa, en cada territorio podían presentar características diferenciadas. Las de Inglaterra e Irlanda, más simples iconográficamente que la mayoría de ejemplos europeos, comparten forma y tipología iconográfica, que se reduce a las figuras de Cristo, la Virgen y san Juan, usualmente sobre soportes en la base de la cruz, aunque también pueden estar presentes los evangelistas y, en menor medida, el monograma IHS. Las del continente, por el contrario, presentan una mayor variedad tipológica. Las cruces españolas e italianas suelen incorporar, además, imágenes de santos, el sol y la luna (Hourihane, 2005: IX, 51-52, 61).

5 El Tetramorfos estaba casi siempre de pie sobre rollos con inscripciones (Hourihane, 2005: 61). Siendo las cruces de término un tipo de obra de carácter eminentemente popular, los textos no estarían necesariamente destinados a la lectura de los viandantes, sino a la propia afirmación existencial de la obra. En España, el uso de la filacteria se prefería al libro (Faison, 1935: 167-168).

6 Pese a que algunos teólogos medievales vieron en ellos la representación de los cuatro sacramenta, los cuatros aspectos de la naturaleza humana de Cristo, en correspondencia con los cuatro momentos principales de su vida: nacimiento, muerte, resurrección y ascensión (González Hernando, 2011: 64).

7 A veces literalmente, como en las ménsulas de la bóveda de la capilla de la Lonja de Valencia, cuya clave central presenta a la Virgen de la Misericordia cobijando bajo su manto a los jurats de la ciudad.

8 Por ejemplo, entre musulmanes y cristianos, tal y como aparece en las Cantigas, donde la cruz acompaña a los soldados junto al estandarte de la Virgen con el Niño (Hourihane, 2005: 42).

9 Es una de estas cruces de cementerio la que Hourihane confunde con una cruz procesional en una miniatura de un libro de horas del sur de Francia. No obstante, la gradería escalonada de la misma es inconfundible y se asemeja a las cruces cementeriales de otras miniaturas francesas [7]

10 En otras partes de Europa se ha podido constatar este hecho a partir del siglo XIV (Martin, 1977: 32-33).

\section{Bibliografía}

BANGO TORVISO, Isidro G. (1984), «La Virgen y el Tetramorfos», Boletín del Museo e Instituto Camón Aznar, n. ${ }^{\circ}$ 15, pp. 15-17. BELTING, Hans (2007), Antropología de la imagen, Katz, Buenos Aires.

BENSON, George W. (1982), The cross. Its History and Symbolism, Harcher Art Books, Nueva York.

COTS MORATÓ, Francisco de Paula (2012), «Símbolo y visualidad en las cruces procesionales valencianas. (SS. XIV-XX)», Laboratorio de arte, n. ${ }^{\circ} 24$, pp. $47-74$.

DE CARLOS, M. ${ }^{a}$ Cruz, «Museo Arqueológico Nacional. Pieza del mes. Ciclo 1999-2001. Creencias, símbolos y ritos religiosos. Cruz procesional. La liturgia católica. Sala 37». En: <http://www.man.es/man/dms/man/actividades/pieza-del-mes/historico/2001-creencias-simbolos-y-ritos-religiosos-3/8-noviembre/MAN-Pieza-mes-2001-11-Cruz-procesional.pdf> (fecha de consulta: 20-11-17).

DURAN-PORTA, Joan (2009), «Adam o Llàtzer? Notes iconogràfiques al voltant de les creus processionals catalanes», Randa, n. 62, pp. 41-58. 
FAISON, Samson L. (1935), "A Gothic Processional Cross in the Museo Cristiano», The Art Bulletin, n. ${ }^{17}$, pp. 163-183.

FAVÀ MONLLAU, Cèsar (2005-2006), «El retaule eucarístic de Vilafermosa i la iconografia del Corpus Christi a la Corona d’Aragó», Locus Amoenus, n. ${ }^{\circ}$ 8, pp. 105-121.

GONZÁLEZ HERNANDO, Irene (2011), «El Tetramorfo», Revista Digital de Iconografía Medieval, 3, 5, pp. 61-74. En: <www.ucm.es> (fecha de consulta: 20-11-17).

GRACIA BENEYTO, Carmen (1998), Arte Valenciano, Cátedra, Madrid.

HERRÁEZ ORTEGA, María Victoria (1994), «Orfebrería y liturgia en la Baja Edad Media. El programa iconográfico de la custodia procesional de Córdoba», Anales de la Historia del Arte, n. ${ }^{\circ} 4$, pp. 783-791.

HOURIHANE, Colum (2005), The Processional Cross in Late Medieval England. The 'Dallye Cross', The Society of Antiquaries of London, Londres.

LLOMPART MORAGUES, Gabriel (1974), «La orfebrería mallorquina en torno a 1400», Mayurqa, 12, pp. 87-121.

MARTIN, Hervé y MARTIN, Louis (1977), «Croix rurales et sacralisation de l'espace. Le cas de la Bretagne au Moyen Age/Rural Crosses and Sacralization of Space. Brittany in the Middle Ages", Archives de Sciences Sociales des Religions, n. ${ }^{4}$ 43, 1, enero-marzo, pp. $23-38$. MOCHOLI MARTíNEZ, María Elvira (2008), «Cruces, caminos y muerte», en GARCíA MAHÍQUES, Rafae y ZURIAGA SENENT, Vicent (eds.), Imagen y cultura. La interpretación de las imágenes como historia cultural, Biblioteca Valenciana, Valencia, vol. II, pp. 1097-1116.

- (2008), «Xàtiva en la encrucijada. La cruz del camino de Valencia», Ars Longa. Cuadernos de Arte, n. ${ }^{\circ}$ 17, pp. 13-23.

- (2017a), Las imágenes conceptuales de María en la escultura valenciana medieval, tesis doctoral, Universitat de València.

- (2017b), «Ostentatio eucharistiae. La significación eucarística de las cruces de término en Valencia a finales de la Edad Media», en BALLESTER MORELL, Blanca y otros (eds.), Encrucijada de la palabra y la imagen simbólicas. Estudios de emblemática, José J. de Olañeta Editor, Palma, pp. 481-494.

NELSON, James (1952), The Medieval Churchyard and Wayside Crosses of Warwickshire, Oxford University Press, Oxford.

PITARCH I VIVES, Teòfil (coord.) (2005), Vallibona/Pena-roja de Tastavins. Fraternitas Saecularis, Diputación de Castellón, Castellón de la Plana.

RÉAU, Louis (2006), Iconografía del arte cristiano. 1.2. Iconografía de la Biblia. Nuevo Testamento, Serbal, Barcelona.

RUBIN, Miri (1992) «The Eucarist and the Construction of Medieval Identities», en AERS, David (ed.), Culture and History, 1350-1600: Essays on English Communities, Identities and Writing, Wayne State University Press, Detroit, pp. 43-63.

SIMÓ CASTILLO, Juan B. (1986), El Maestrat para andar y ver, Radio Nueva, Vinaroz.

ZARAGOZÁ CATALÁN, Arturo (1999), «Sueños de arquitecturas en el episodio gótico valenciano», Penyagolosa, n. 1, pp. 9-18. 
